HStud 27 (2013)2, 325-342

DOI: 10.1556/HStud.27.2013.2.9

\title{
DICTATORSHIP, INFANTILISATION, AND THE FOCALIZATION OF A CHILD: ZSUZSA RAKOVSZKY'S $A$ HULLÓCSILLAG ÉVE (THE YEAR OF THE FALLING STAR) AND FERENC BARNÁS' KILENCEDIK (THE NINTH)
}

\author{
EDIT ZSADÁNYI \\ University of Groningen, The Netherlands \\ E-mail: ezsadanyi@gmail.com
}

\begin{abstract}
In my paper, I call attention to a literary trend of contemporary Hungarian prose fiction, in which the communist past is narrated from a child's point of view. I will concentrate on the relation among the focalization of the narrative through the eyes of a child, the theme of dictatorship, and present-tense narration. I will relate my approach to Gayatri Chakravorty Spivak's ideas on the problem of representing disempowered people, in other words, representing the subaltern. I take the narration of a child situated in a fictional dictatorial time as a special case of giving voice to the subaltern. In the first part of my paper I will address the theoretical and narratological problem of giving voice and understanding the subordinated figures. The second part consists of the analysis of the novels by Zsuzsa Rakovszky and Ferenc Barnás. I will argue that the communist past is a counterfeit referent since it is narrated by an unreliable child narrator. The object of representation is not the historical past but it is itself the perspective of the child through which we come to understand a hidden pattern of dictatorship: infantilization.
\end{abstract}

Keywords: focalization of a child, subaltern studies, unreliable narration, dictatorship, communism

Fictional narratives of the last decade have often emphasized that history is (pre)written in our body and our mind. Unlike politics, contemporary literature helps us to work through - and thus move beyond - our communist past. It may also reveal the hidden mechanisms of power that are still with us; that we unwittingly and automatically produce and reproduce as inherited cultural patterns. In my paper, I would like to call attention to the active role that contemporary Hungarian literature plays in working through the country's communist past - a role that is of special importance in constructing our cultural identity today. It is fascinating to see a recent literary trend of contemporary Hungarian prose fiction, in which the communist past is narrated from a child's point of view. I speak specifically of those cases in which the events are focalised by a child (for example: György Dragomán's A fehér király (White King) (2005); Ferenc Barnás' 
Kilencedik (The Ninth) (2006); Zsuzsa Rakovszky's A hullócsillag éve (The Year of the Falling Star) (2005); Gábor Németh's Zsidó vagy? (Are you Jewish?) (2004); Attila Bartis' A nyugalom (The Tranquility) (2001); Endre Kukorelly's Tündérvölgy (The Fairy Valley) (2003) and László Garaczi's Pompásan buszozunk (We Bus in Splendor) (2001). ${ }^{1}$ What could be the reason for the appearance of such a great number of books written in the horizon of a child? What can we learn from these "children" about our past and present? Whose voice are they articulating? I wish to illustrate that putting aside fictionality and approaching these novels with questions such as "what was communism like as a child?" proves inappropriate since information offered by the infant narrators unavoidably carries ambiguities. Instead of giving an answer to this question, the novels initiate an interactive relationship with the reader: we should participate in the fictional circumstances of the novel and experience the subordinated position of the child narrator in dictatorship. In this way we can understand and feel a characteristic cultural pattern of Eastern European inheritance.

I will put the recent political interest in Hungarian literature into the framework of the literary theoretical interest towards political issues of human rights, justice and equality in which poststructuralist ideas are redeployed in ways that emphasize socially and politically important issues, and I will relate my approach to Gayatri Chakravorty Spivak's ideas on the problem of representing disempowered people, in other words, representing the subaltern. When studying Hungarian novels, I will concentrate on the relation among the focalization of the narrative through the eyes of a child, the theme of dictatorship, and present-tense narration. I take the narration of a child situated in a fictional dictatorial time as a special case of narrating, thus giving voice to the subaltern. To be able to understand the special importance of the point of view of the child, I will also rely upon the narratological scholarship on the unreliable narration since the child narrator does not have complete knowledge about his or her circumstances and the reader's active role as possible correction is built into the interpretative functions of the novel. In the first part of my paper I will address the theoretical and narratological problem of giving voice and understanding the subordinated figures. The second part consists of the analysis of the novels by Zsuzsa Rakovszky and Ferenc Barnás.

It seems characteristic of contemporary Hungarian literature to express new solidarity with the people and provide help for their problem-solving strategies. Many of today's writers continue the long Hungarian tradition of addressing social issues. One of the key characteristics of postmodern Hungarian fiction is that it combines interest in ethical-political issues with typical postmodernist views and 
techniques such as intertextuality, meta-fiction, the combination of different voices, and challenges to the self-centered notion of the subject. This tendency could be seen as an East-European version of postmodernism, or might well be considered to belong to the recent post-postmodernist ethical turn.

In the last decade a number of theoretical publications appeared that stressed the importance of politics, ethical, social and racial issues, gender and sexuality when arguing for the new roles that Humanites can play in the globalized world. Poststructuralist theories have been appropriated and redeployed in politically invested fields, such as race, colonialism, sexuality and gender. According to the introduction of the volume What's Left of Theory? New Work on the Politics of Literary Theory (Essays from the English Institute), "the value of post-structuralism no longer forms the pivot of contemporary debate, but rather, its place in new forms of cultural and political analysis is both inchoate and central" (Butler, Guillory, Thomas, 2000, xi). When interpreting the Hungarian novels, I also wish to situate my reading into a "redeployed" poststructuralist perspective that is engaged with social and ethical issues.

This article may offer a narrative way to give voice to the unvoiced subalterns in culture. Lack of self-reflection is a key element of subaltern existence. I examine the problem of reflecting upon non-reflected human existence in highly repressed social positions, as subaltern experience. In these novels children as subaltern characters accept their lives under communist dictatorship as normal. They were born into this system, they consider it as natural cultural environment since they have no chance to compare it with another. When they come across with strange states of affairs or find themselves in a discriminating situation they try to understand them with the help of their fantasies. All works foreground the lack of reflection of their infant characters. In other words, they reflect upon non-reflected existence and they relate this entire dependant position to a special kind of experience of dictatorship.

After two decades of discussions of the problem of representing the subaltern, there is still a huge distance between the theoretical discourse on the subaltern and the practical programs of solidarity to help the subalterns (Chakrabarty, 2000; Cherniavsky, 2011). In her provocative and inspiring arguments Gayatri C. Spivak claims that the subaltern cannot speak the language of the dominant discourse. She convincingly claims that benevolent western intellectuals and politicians paradoxically assimilate and appropriate, thus silence the disempowered people by speaking on behalf of them. Political representation cannot guarantee that subordinate groups will be recognized or that their voices will be heard since it cannot avoid objectifying and simplifying the complex position of the excluded "other" (Spivak, 1988; 1999).

I wish to develop the argumentation precisely at this point and will illustrate that the subaltern can speak in a rhetorical narrative language. The examined nov- 
els do not speak on behalf of the unrecognized groups of children and they do not objectify them. They do not simply talk about disempowered people, but give voice to disempowered positions. The participation of the reader is also encoded into the textual world because the limited knowledge of the infant narrator needs constant correction throughout the entire reading process. I wish to demonstrate that it is possible to translate the complex problem of giving voice to the subalterns into the complex narrative discourse of reflecting upon the (non-reflected) perspective of the child.

In some works by contemporary Hungarian female writers, similar ways of narration foregrounding the problem of non-reflection can be observed in which female figures accept their hopeless way of life as normal and given. In the fictional world, they are not given any chance for improving their life or develop further their talents. They accept it as an unchangeable world order which assigned subordinated position, surrender and suffering for women. For instance in the poem Portré (Portrait) by Virág Erdős the speaker uses a registrative tone, listing the atrocities against women one after each other without creating logical order among them and without making any comments on them. In the poem Porhó by Kriszta Tóth, the fast switch between the position of the speaking subject and the represented female figure as object creates a special in-between discursive position for the suppressed female figure, in which her subordinated situation can be represented in a complex rhetorical structure. These poetical strategies successfully avoid the objectification and appropriation of the excluded other, which is criticized by Spivak. These works do not speak on behalf of them and do not objectify and simplify the subaltern figures while they do represent their interests.

The novels by Ferenc Barnás and György Dragomán are entirely written from the point of view of a child. All developments are narrated and focalized by the child. The words of the child are sometimes interwoven by characteristic images and discursive elements of the adult world. Zsuzsa Rakovszky's A hullócsillag éve (The Year of the Falling Star) consists of chapters that are focalized by a child and other chapters which are narrated and focalized by adult narrators. One chapter consequently keeps one dominant viewpoint. The construction of different chapters representing different viewpoints creates a complex multi-perspective structure and provides characteristic fictional personal histories taking place in the 50s in Hungary. The novels by Gábor Németh and Endre Kukorelly present a further complicated combination of perspectives. Often within the same paragraph, they frequently rotate the reflective and remembering focalization of an adult with the unreflective and contemporaneous focalization of a child.

The Sorstalanság (Fateless) by Imre Kertész, an account of the comprehensive dictatorship of a German concentration camp, is also narrated from the perspective of a child. Published in 1970, it clearly criticized the communist regime of the time. The story - of how an adolescent boy experiences the German concentration 
camps - is written from the point of view of a child who does not initially realise what is happening to him. The discrepancy between the reader's knowledge and that of the boy creates a special atmosphere of the novel. This discrepancy evolves throughout the narrative as the child acclimates to the world of the concentration camps and in the end becomes much wiser than any reader. The book gave important information about the mechanism of dictatorship at the time of its publication. Péter Szirák claims this was part of the reason that it was not popular during the Kádár-regime (Szirák, 2003, 16). The above-mentioned novels, written from the focalization of a child, can also be seen as following the example set by Imre Kertész's Sorstalanság; and further exploring totalitarianism from a child's point of view.

The narrator's lack of knowledge, a sort of unreliability, is usually mentioned in narratological scholarship when discussing narratives written in the focalization of a child. According to Wayne C. Booth's classical, oft-quoted definition, the narrator is reliable "when he speaks for or acts in accord with the norms of the work (which is to say the implied author's norms), unreliable when he does not" (Booth, 1983, 158-9). In investigating Stevens's narration in Kazuo Ishiguro's The Remains of the Day, Phelan and Martin further develop Booth's notion of the unreliable narrator into different axes. To summarize, they claim that narrators may deviate from the implied author's views in their roles as reporters, as evaluators, and as readers or interpreters. Unreliable reporting occurs along the axis of facts/events; unreliable evaluating occurs along the axis of ethics/evaluation; and unreliable reading occurs along the axis of knowledge/perception. Audiences perform two different actions once they determine that a narrator's words can't be taken at face value: they reject those words and try to reconstruct a more satisfactory account, or they accept what the narrator says but then supplement the account. Combining the activities of narrator and audience, they identify six kinds of unreliability: misreporting, misreading, misevaluating, underreporting, underreading, and underregarding (Phelan and Martin, 1999, 93-5).

Gerald Prince refers to the figure of the narrator as a "limited point of view or focalization that is subject to conceptual or perceptual constraints as opposed to omniscient point of view" (Prince, 1987, 48). William Riggan examines four distinct types of unreliable first-person narrators: the pícaro, the clown, the madman and the naïf. The last seems to most closely fit the narratives written from a child's point of view I explore here. Analyzing the narration of two adolescent figures, Huck in Mark Twain's The Adventures of Huckleberry Finn and Holden Caulfield in J. D. Salinger's The Catcher in the Rye, he comes to the conclusion that these works present social critique through the eyes of one who has not yet entered the social world and who is largely unfamiliar with it on any direct, experiential level. The madman's unreliability as a narrator is different from the unreliability of a 
naïve narrator with respect of their involvement in the society they inherently criticize.

\begin{abstract}
And unlike the madman's narrative, where the narrator's derangement not only indicts but also often reflects the social, political, and/or spiritual malaise of the society and era which spawn him, the naïve narrator embodies in his actions, words, and characters a positive opposing spirit to the malaise, though he may demonstrate some of its superficial symptoms. [...] His critique, whether consciously uttered or whether conveyed over his head from implied author to reader, thus does not work to his discredit but rather the opposite, despite his frequent confusion and error as he attempts to describe and come to terms with a world still beyond his ken. Though incapable of fully reliable articulation, he nonetheless reveals himself through his narrative as positive figure (Riggan, 1981, 169-70).
\end{abstract}

I have found this argument especially relevant for my work because it emphasizes the outsider status of the narrator in relation to his social environment. My emphasis is not on the positive feature of the naive narrator but rather on the fact that by not fully comprehending the symbolic order around him or her, he or she is not fully absorbed by the system. Instead the narrator remains a lonely outsider, an observer who accepts the circumstances of his life as a given and unchangeable order.

Ansgar Nünning argues for a synthesis of cognitive and rhetorical approaches in understanding the concept of the unreliable narration. He convincingly claims that the problem of unreliable narration cannot be resolved on the basis of textual data. It is a pragmatic phenomenon that cannot be fully grasped without taking into account the conceptual premises that readers and critics bring to texts (Nünning, 2008, 45). He mentions two referential frameworks: the first refers to the reader's empirical experience such as the general world-knowledge, the historical world-model or cultural codes, explicit theories of personality or implicit models of psychological coherence and human behavior of the reader or the critic. The second framework involves a number of specifically literary frames of references. These include, for example, conventions and models of literary genres, intertextual frames of reference, stereotyped models of characters such as the picaro, the miles gloriosus, the trikster, and the structure and norms established by the respective work itself (47-8).

\title{
II
}

In this section I will illustrate how the works of Zsuzsa Rakovszky and Ferenc Barnás unite the narration of history in the present tense with the focalization of a child. 
The novel $A$ hullócsillag éve (The Year of the Falling Star) ${ }^{2}$ by Zsuzsa Rakovszky takes place in a small town close to the western border of Hungary in the years 1955-56. The main part of the novel is a collection of lyrical scenes, impressions of a 5 year-old child named Piroska. This is a crucial time for the young girl because she has to leave the relatively safe environment of her home and enter society, first in kindergarten and then primary school. Her impressions are interwoven with some sentences that she overhears from the adults around her - family members and friends of her mother. Through these "adult sentences", presented as quotations in the child's interior monologues, the adult reader tries to reconstruct the historical background. The novel also contains letters and diaries of the other characters. Considering these pieces together with the child's narrative, we can construct a developing story line, in which we see the evolution of the characters, even if we are not presented with an entire life-story.

We learn that Piroska's mother, Flóra, is in love with a man who is sensitive, ironic, and not very honest. He is emotionally terrorized by a woman who is a member of the AVH, the Hungarian Secret Service. We also get to read the letters of the tenant of Flóra, who falls in love with her. He has come back from the Gulag, and approaches her with an increasingly aggressive, male chauvinist attitude. We are also party to all the love stories around the family during the rigid dictatorship and deep poverty of the $50 \mathrm{~s}$. We read a kind of fictional micro-history, seeking the answer to the question of how history looked in everyday life. The fragmented structure also reminds us that history is not available to us as a single, comprehensible story.

Learning the past from the perspective of a child is very problematic since he or she is a sort of unreliable narrator. Even if the audience accepts what the narrator says, the account needs constant supplementation, as the reader strives to correct the story all the time as was suggested by Phelan and Martin. In this case, we have to activate our historical knowledge about the everyday terror of the fifties in Hungary. But the problem is that this is exactly what we may want to know: that side of the story which is not readable in history books and cannot be seen in documentaries. These novels, because they are narrated by unreliable young storytellers with limited knowledge of their own circumstances, will never give an acceptable answer to our curious question: what was dictatorship like in these years as a child? In other words, a child, by definition, cannot narrate on history. He or she is not able to tell his or her own story. These narratives are always misleading, both offering an insight into marginal perspectives on history and confounding this perspective at the same time. The child's version of history must always be supplemented by an imagined history that we try to construct on the basis of the child's views in order to understand what the child's specific view is. We are invited to read the novel as if it were the story of the child in the fifties, and in the end we must face the fact that it gives us only very vague references to the facts of his- 
tory. It cannot be a coincidence that, in approaching history, all of the mentioned novels are unsuitable for referential reading. They emphasize textuality and fictionality in several ways, thus challenge the illusion of arriving at the actual (historical) reference. And yet, we do learn a lot about the nature of despotism and we learn it from children.

We learn that dictatorship produces differences in terms of age and gender. For instance, in this novel all the male figures, though they themselves may suffer severely from dictatorship, assume a dictatorial manner toward the female figures without any hesitation. This is displayed either through tyrannical behavior or incorrect treatment such as cheating and lying, which were the basic principles of the authoritarian system. In the novel by Zsuzsa Rakovszky, using a child's point of view may call attention to the fact that in many cases children suffer from a double suppression. On the other hand, a counter-story can also be read in the same novel: the adults try to shield the children from the effects of the system; they try to raise them according to bourgeois principles in a non-bourgeois political system. The fictional world suggests both meta-narratives of a child's life-story as they are inscribed into the development of the storyline. Let us turn to a case for the double suppression viewpoint, in The Year of the Falling Star. The little girl and her mother visit an elderly lady from a former bourgeois family, whose son or close relative could be the victim of the communist regime. It is clear for the child that it is her lost son whose portrait is hanging on the wall. The lady once goes up to this portrait and lights a candle under it. Whether it is an act of reverence or simply saving money by not using electricity, is not obvious. We follow stage by stage this kind of partial understanding of the girl throughout the entire book. The following passage consists of two paragraphs: one is the storytelling of the elderly lady; the other is the reaction of the little girl.

Ott találták meg a fák között, alig pár száz méterre a házuktól... Szörnyülködő, diadalmas suttogás a vaniliás kifli porcukor-csillámporos maradéka fölött. - A biciklire figyeltek föl, ott hevert az árokparton, gazdátlanul... Süket volt szegény, mint az ágyú, azért nem hallotta meg, amikor a határőrök utánakiabáltak, hogy hová megy... Azok is rájöhettek, hogy bakot lőttek, hogy úgy mondjam... Bevonszolták a szerencsétlent a fák közé, egy kis avart kapartak rá... Most gondold el: az is lehet, hogy akkor még élt!

Piroska fejét az anyja válla gödrébe fúrja, de hiába, nem bírja elhessegetni a képet, a holttestet a fák között, a száraz levelek alatt. Gyanútlanul átlépett egy határt, azért hihették róla, hogy egy másikat is át akar lépni, egy még tilosabbat. Lehet, hogy a vércseppek mutatták az utat a falubelieknek, mint a Jancsi és Juliskában a fehér kavicsok? Lehet, hogy másutt is halottak vannak eldugva az avarban, a Papréten vagy az udvarukban? Segélykérően körülnéz. Az özvegy két tenyerét az asztallapnak vetve föltápászkodik, a varróasztalkához 
döcög, és ünnepélyes mozdulattal meggyújtja a gyertyát. A hátrafésült hajú fiatal halott szomorúan és igyekvően néz vissza Piroskára. (Rakovszky, 2005, 38)

They found him a few hundred meters away from his house. - Lamenting, triumphant whisper above the leftovers of the vanilla croissant glittering with powdered sugar. - The bike has been seen upended, lying in the ditch, unattended... The poor man was deaf, that is why he did not hear when the border guards shouted at him asking where he was going. Later on they realized that they made a blunder. They dragged the poor man into the trees and scraped some litter over him. Imagine! He might have been alive!

Piroska snuggles into her mother's shoulder in vain, she cannot help thinking of the scene, the dead body among the trees, under the dry leaves. He crossed a border unsuspecting, and they thought he wanted to cross another border, a more forbidden one. It might be that it was the drops of blood that showed the villagers the way, like the white stones in Hansel and Gretel. It might be that there were other dead bodies lying under the litter, in Paprét, or in their backyard. She looks around helplessly. With the help of her hands, the widow struggles to her feet, shuffles to the sewing table and with solemn motions lights the candle. The young dead man from the picture on the wall looks back at Piroska with a sorrowful and responsive look. (My translation - E. Zs.)

We see the events from the focalization of a child, thus we need to supplement the information. We can activate our knowledge about the closed borders in the fifties in Hungary and may better understand the story of the woman than the child does. Yet it remains unclear whose story it is and when exactly this took place. Is it the story of her son or that of somebody else? We do not know for certain, and the text does not give any clues. As an adult reader, we have a partial understanding about the referent of the story. Using historical references we might get a better picture, but it always remains ambiguous.

What is unambiguous is that the girl is struggling to understand the world around her. What we clearly see - and here a shift in the referent of the story occurs - is the child's view. We learn that a threatening political power which uses unclear information as means of intimidation is even more threatening for a child. She confuses the elements of the political terror with the brutal elements of the tale. She has to cope with an extra fear that might be well beyond the anxieties of a typical child of the same age.

In the story we follow how her mother tries to defend her from the effects of the political system as much as possible, for instance by postponing her enrolment into kindergarten. And we also quickly realise that it is an impossible goal. She cannot protect her from the entire (textual) environment. The effects of the social system touch her through the fragments of stories and unfinished sentences. She 
supplements information from her own stock of knowledge, in this case fairy tales. The result of this combination is even more brutal than the fictionalized political reality of the time. In this case, Piroska has created a universe with dead bodies lying all around. The reader cannot help but recognize that children sometimes suffer more from dictatorship than the adults.

Her view, like a reading glass, reveals how the system works. We read the events through her reading glass. What we clearly see is her way of observing the world. The perspective of the reading glass becomes the real referent. Not only do we see through the child's eyes, but experience her view of reality. This view is a constant element throughout the reading process alongside the communist regime that regulates and poisons the people's lives. It is not difficult to come to the conclusion the novel suggests and repeats several times that this outlook somehow belongs to the system. Not completely understanding what is going on yet being completely controlled by it, this is the child's experience of dictatorship. Instead of the actual historical referent, the childish view is the referent; this is what we are invited to discover: the focalization of the child is one of the key peculiarities of despotism. This kind of knowledge about political terror can be represented by complex artistic narration like this but is difficult to express on the pages of history books.

Narrative cognition on totalitarianism may be further developed when studying more examples from the work. So far, I have concentrated on the viewpoints of the child; let us make the picture more complicated by taking into consideration the speaking positions and the time of the narration.

- Hanem - mondja a nagyanyja, és az anyja karjára teszi a kezét, elöre is bocsánatot kérve azért, amit mondani fog -, múlt vasárnap nem jöttetek. Persze, tudom, hogy rengeteg dolgod van - vág közbe sietősen, amikor Piroska anyja mentegetőzni kezdene -, még mindig jársz arra a tanfolyamra? Szegénykém... Még szerencse, hogy engem már nem gyötörnek ilyesmivel... Engem szerencsére már senki nem akar átnevelni arra a kis időre... Az én öreg csontjaimra már nem érdemes annyi energiát pazarolni...

- Te nem is vagy még öreg! - támad rá Piroska zsarnokian és szemrehányóan. (Rakovszky, 2005, 45)

- But, says her grandmother, putting her hand on her mother's arm, apologizing in advance for what she is about to say - you did not come last Sunday. Of course, I know, you are very busy - she quickly interrupts Piroska's mother when she starts to apologize. - Are you still attending that course? Poor thing... Luckily they don't want me to do such things. Luckily nobody wants to re-educate me for that little time left... It is not worth wasting energy on my old bones...

- You are not at all old - Piroska attacks her tyrannically and reproachfully. (My translation - E. Zs.) 
- Hanem Flórikám... - Megint a szégyenkező, puha nevetés. - Nem tudsz véletlenül egy kis varrónőt, aki olcsón dolgozik, de tényleg olcsón? Tudod, a kosztüm... És Flórikám... - Újabb nevetés, ezúttal zavart és kínos. - Lenne még az a korall nyakláncom, tudod melyik, talán érdekelné valamelyik kis kolléganődet... Esetleg azt, amelyik a pillangós brosst megvette a múltkor...? (Rakovszky, 2005, 47)

- Well, dear Flori - again the shameful, soft laugh. - Do you happen to know a dressmaker who works for a low price, really low? You know my outfit. And dear Flori... - Another laugh, this time confused and embarrassed. - Here is my coral necklace, you know which one, one of your kind colleagues might be interested... Maybe the one who bought the brooch with butterfly last time. (My translation, my emphasis - E. Zs.)

Apart from the point of view of the child, the most striking feature of Piroska's sections is that, throughout the entire book, they are written in the present tense. In the beginning, this is clearly a disturbing element that might confuse the reader. The story obviously takes place in the past; the crucial historical period is 1955-56. The present tense can be interpreted as bringing this story into the reader's own present with constant disturbing effects.

What does the present tense tell us together with the limited focalization? Considering focalization, the story is told from the point of view of the child. Grammatically speaking, it is told by a neutral, rather impersonal voice, a third person narrator saying "anyja" (her mother). Rhetorically speaking, an adult view providing subjective evaluation breaks into the focalization of the child with such expressions as: szégyenkező, puha nevetés; Újabb nevetés, ezúttal zavart és kínos. ("the shameful, soft laugh"; "Another laugh, this time confused and embarrassed"). It is of course possible that the child senses the embarrassment of her grandmother, yet in the mood as a narrative account of speech, an adult commentator's perspective is present. In this combination of voices the reader may again experience constant disturbing effects just as with the present tense narration.

As fictional micro-history is brought close to us, we are faced with a historical experience and also the fact that, in one way or another, this history is still with us. We can compare the above text with our historical knowledge. People were forced to participate in different re-education programs and there was poverty all over the country, especially in the circle of the former bourgeois class. There is no sign that the child understands the cultural and political background. This atmosphere of not understanding what is happening around us but being subjected to the circumstances characterizes the dominant perspective of the work.

When reading the novel from the child's view we realize more and more that this infantile outlook imposed upon the reader characterizes the mechanism of the political regime. It is not only that we have a different perspective providing addi- 
tional information. Infantilisation, forcing the people into an infantile position, lies at the heart of the repressive mechanism. Nünning claims that the reader tries to account for textual inconsistencies by reading the text of an unreliable narrator. In this process accepted cultural models of deviant (in our case limited knowledge of the infant) but plausible human attitude or behavior are made use of, and the text begins to become naturalized. This process can be understood as "mechanism of integration" (Nunning refers to Yacobi, 1981, 119) in that it resolves whatever contradictions or discrepancies between the textual data and the reader's world knowldge there may have been and leads to a synthesis at a higher level (Nunning, $2008,48)$. When the reader in this novel identifies the inconsistencies in the narration of the child and realizes that it is not possible to see beyond her perspective, he or she can resolve this problem that leads to a synthesis at a higher level, namely, recognizing that infantilisation is a recurring epistemological problem of the text, as well as a hidden dictatorial way of manipulating and subordinating the people. If we want to understand what dictatorship is we should understand that we are forced into the position of a child which equates to dependency and partial understanding of what is happening around us, with others arranging outcomes above our head.

The present tense alone creates tension in the interpretation. Combining the narrative present with third person (adult) narration and the internal viewpoint of a child when dealing with the historical situation of the fifties, seems a bizarre and unusual narrative approach. Monika Fludernik lists a few typical examples of the present tense narration, among them Pynchon's Gravity's Rainbow, J. M. Coetzee's Waiting for the Barbarians, and the nouveau roman literature. However, none of them presents a narration based upon the above combination.

Even so, Fludernik's conclusions about present tense narration are of importance in my case. "The loss of the deictic distinction between present tense nows and past-tense thens is therefore implicated in the loss of even more crucial narratological distinctions: that of story and discourse." (Fludernik, 1996, 254) "Most present-tense narratives, however illogical, are easily recuperable as a story of events or as the representation of a mind reliving past experience as present. Hence the paradoxical situation is that the narrative present is both a rather unknown oddity and a technique of unremarked-upon familiarity." (Flaudernik, 1996, 256) The present tense makes it difficult to keep distance from the story, so we easily experience it as our own. It might remind us that these power mechanisms are still with us, we carry their effects and resulting behavioral patterns.

We see for ourselves how mother and daughter try to resist their circumstances throughout the novel. Piroska has difficulties with eating; her body protests against the social sphere which surrounds her. Her mother tries to follow an authentic life and is looking for someone she can really love. The novel ends with her complete surrender. Flora marries "the good man", her tenant who returned 
from Gulag and is ready to give her the recipe for the "right" way of living. Even he wants to re-educate her. In this way, in the personal sphere, like all the other male figures in the novel, he repeats the government's despotism towards the woman.

Piroska's bodily fight against (eating in) the kindergarten also ends in absolute surrender.

- Megtömlek én, édes fiam, mint a libát, ha neked ez kell...

Fuldokolva nyel: a következő kanál elől megpróbálja összeszorítani a fogát, de az óriáskéz kétfelől erősen, fájdalmasan megnyomja az arccsontját, a szája akarata ellenére kinyílik. Igyekszik rágás nélkül lenyelni, amit a szájába tömtek, hogy ne érezze a húscafatok ízét. [...]

Egy húsdarab megakad a torkán: vajon most meg fog halni, mint Hófehérke a mérgezett almától. [...]

- Ugye mondtam, hogy meg fogod enni?

Az óriásnő barátságosan gúnyos, csillogó szemmel, majdhogynem cinkosan néz le rá, őt pedig alázatos hála önti el, amiért már nem haragszik rá. Nyekeregve együtt nevetgél vele, hogy mutassa, ő is pontosan ugyanúgy vélekedik arról a nevetséges lényről, aki ő még öt perccel ezelött is volt, mint az óriásnő. A gyomrára szorítja a kezét: egész engedelmes testében már csak az lázadozik háborogva. - Te, ha nekem most hányni mersz...! (Rakovszky, 2005, 390-1)

- I feed you up, my dear child, as you do with the goose, if you want this...

She swallows and suffocates: she tries to close her teeth before the next spoon, but the big hand heavily and painfully presses her cheekbone from both sides, her mouth involuntarily opens. She tries to swallow without chewing the meat, which is stuffed in her mouth, so as not to feel the taste of the bits of meat.

A piece of meat stuck in her throat: Is she going to die, like Snow White from the poisoned apple? [...]

- I told you that you would eat, didn't I?

The Giantess with friendly, sarcastic and bright eyes, is looking down at her almost with complicity. She feels a humble gratitude towards her because she is no longer angry with her. She laughs creakingly together with the Giantess to show that she thinks exactly the same way about the ridiculous creature she was just five minutes ago. She pushes her hands against her stomach: only this part revolts in all her obedient body.

- You, if you dare to throw up now...! (My translation - E. Zs.)

After this aggression, Piroska is defeated and finally falls asleep as she never did beforehand in the kindergarten. This can be seen as abandoning resistance, something that happened frequently in the history of Hungary after direct aggression, 
as in 1956. And yet, it cannot be a coincidence that the following chapter tells the story of how Piroska flees from Hungary with her mother and grandmother and reaches the border at night. Is it a dream of Piroska's? Or is it a "pseudo-ending" as Györgyi Horváth saw it (Horváth, 2006)? It is hard to decide.

Since the novel was published in 2005 , and is narrated in the present tense, one cannot help but see the main features of intimidation, lack of prospect, making the people infantile, forced surrender and radical refusal as recurring patterns in our past and present. We are growing accustomed to a strange narrative manner. This reading strategy of "growing accustomed" brings us face to face with a "cultural trope", a modus vivendi too well known in the East-European region: growing accustomed to and learning to live together with the unacceptable.

Ferenc Barnás's novel, The Ninth (2006) is the story of a nine-year-old boy in communist Hungary. He is the ninth child of a Catholic family who live in deep poverty on the margin of society. Because they openly keep their religion, their life is even more miserable than the average Hungarian's at the time. They do not have enough basic furniture such as beds, chairs and a table. There is never enough food and clothes and they always run out of firewood. Most of the children suffer from speech and behavioral disabilities. The father practices several forms of dictatorial behavior within the family despite the fact that he himself lives under the pressure of the communist political system. He uses his children's labor for his enterprises to make money. He prevents them from any form of enjoyment and punishes them physically on a regular basis.

The young child simply registers the events around him. He is an observer, as a critic reading the English translation comments:

\footnotetext{
The picture we gain from our young narrator is uncomplicated by subtlety, politics, morality, and without the self-conscious morbidity and sexuality found in so many adult narrators. He's an observer.[...] Our pathetic unnamed protagonist observes the realities of his own family's survival, of his father's obsessive small-time industry, his mother's fervent religiosity, the difficulties of his siblings, and the cruelties and indignities of life in poverty (Waxman, 2009).
}

Poverty and lack of personal freedom are deeply interrelated. Poverty is itself dictatorial because of the limitations it places on life chances. In such a situation - in which children suffer from several levels of oppression: the father, the cruel realities of poverty and the political system - there is not much space for more psychologically complex dimensions such as dreams, fantasy, or creativity. When the basic needs such as for warmth, food, safety and privacy, are unmet - summarizes Mátyás Dunajcsik - there is no chance for the development of a sophisticated personality since all the individual's energy is needed for surviving one day after the 
other. The symbolic sign of this underdeveloped mental state is the speech defect of the children, and as a result, they hardly speak at all, even to each other (Dunajcsik, 2006).

Let us look more closely at an example from the beginning of the work in which the child-narrator tells the daily routine of the family.

Fél öt körül, amikor Ésapa munkába indul, felébredek. Ésapa továbbra is a MÁV-nál dolgozik, de most a rákoskeresztúri Állomásfőnökségen, ahol nemrég pluszban elvállalta az ellenőrséget. Kénytelen hamar megtanulni az új szakmákat, mert amíg építjük a Nagyházat, igazából nem kegytárgyazhatunk. Ésanya öt felé kell fel. Ezt onnan tudom, hogy utána mindjárt kimegy az utcára, ahol valakitől megkérdezi a pontos időt. Ha délelőttös, mindig ezt csinálja. Az első gyưjtésen nem kaptunk órát, neki viszont nem szabad elkésnie a szentendrei Tollgyárból. Nemrég vették fel ide, két műszakba. Ésanyának a szülések miatt nincs szakmája, ezért golyóstollakat kell összecsavaroznia. Amíg készülődik, úgy teszek, mintha aludnék, akár a többiek. Fejem a takaró alatt, Tentés lába az arcomnál; eltolom magamtól, mint máskor is. Aztán megpróbálok visszaaludni, de nem sikerül. (Barnás 2006, 8)

At four-thirty, when Papa leaves for work, I wake up. Papa still works for the state railway, but now he's at station headquarters in Rákoskeresztúr, where not long ago he accepted the post of watchman alongside his regular job. He's got to learn new trades, because once we're busy building the Big House, we really can't be spending all our time at home making devotional objects to sell to churches. Mama wakes up around five. I know this because she then goes right out to the street and asks someone for the exact time. She always does this when she's on morning shift. The first time the church up in Budapest organized a benefit drive for our family we didn't get a clock, and she can't be late for work at the pen factory in Szentendre. She was hired there not long ago for two shifts. With her having kids all the time, Mama never got a trade, which is why she's got to screw ballpoint pens together all day long. While she's getting ready I pretend to be asleep like the others. My head is under the pillow and my brother Teeter's foot is right by my face; I push it away, as at other times. Then I try getting back to sleep, but it doesn't work. (Translated by Paul Olchváry)

The narrative point of view recalls and rewrites at the same time the modernist manner of subjective storytelling. It maintains the illusion of a coherent personality, but since it is a limited perspective, it always requires constant correction from the reader. When we consider the act of challenging the idea of a cohesive personality for the narrator to be a characteristic poetical-philosophical view of postmodernist narration, then this could be seen as a reinterpretation of the modernist narrative tradition. 
The Ninth is a narrow-minded, closed narration, but since the adult reader's presence is always presupposed as an inbuilt narrative perspective, another view is added as a supplement. This one-way viewpoint is seen here as merciless, and thus dictatorial. The reader is also enclosed in this world dictated by the body and can feel for himself the merciless, dictatorial, one-perspective and one-storyline narration of the single-party system. This "traditional" narration gains additional significance when considered in the context of contemporary post-modernist Hungarian fiction. One of the characteristic postmodernist narrative strategies of Hungarian novels nowadays is to present several voices instead of one. Moreover, in many cases these voices are not necessarily attached to a person, rather we hear several disembodied voices, such as common sense slogans, clichés, political speeches, slang and advertisements.

In this narrative-cultural environment, the narrow perspective of a personal narrator could be seen as an old-fashioned manner of speech as well as a postpostmodern view putting ethical issues of social solidarity into the foreground. This narrative view emphasizes the loneliness and inaccessible position of people in deep poverty, who are just talking to themselves (like homeless people on the streets), and highlights the danger of lack of communication between welfare and poverty. It calls attention to a dangerous phenomenon in our contemporary culture - that in losing contact with the mainstream structure, one can easily get trapped in a marginal and hopeless situation. This book is also a sort of lonely piece in the literary environment as it does not participate in the dialogue with the strategies of typical contemporary Hungarian novels. Thomas Cooper also considers this work as a non-canonical Hungarian novel and hopes that the English translation by Paul Olchvary creates a wider interest in the English speaking audience, among those who are still interested in the communist times in Hungary (Cooper, 2009). In sum, the novel conveys the problem of lack of communication in several different ways. Where is the hope in this chronicle of hopeless poverty? Perhaps it is to be found in the narration of the habitual present, which puts emphasis on the position of the reader. Telling stories in the habitual present tense implies that there must be a listener who is interested in this daily routine of suppression. The hope lies in the presupposed figure of the reader.

What have we learnt, then, from these children telling the past in the present tense? First of all it has become clear that the communist past is a counterfeit referent and the object of representation is not the historical past but it is itself the perspective of the child. Paradoxically enough, the narratives denying dictatorship as referent, do provide important information about its nature. This narrative perspective makes the special historical situation accessible to a certain extent for those who did not experience it personally, since it invites the reader to experience the fears and anxiety of the child. The inherent contradiction in the limited perspective of the child challenges the (child-like) desire to have direct access and 
understanding to our past. The "what was it like?" question seems to be inappropriate, and we will never get an answer with the help of such young narrators. Barnás' novel reminds us of the dangerous historical - and present-day - phenomenon of a lack of communication between the mainstream and marginal segments of Hungarian society. This can be read as a warning sign for our future: we are losing communication; deep poverty traps people in an isolated world. Present tense narration supports the idea that what is at stake here is not the past event but rather its legacy - what we have been carrying with us ever since. Instead of the historical referent, we can learn through the present tense and the infantile horizon that patterns of infantilisation are still with us. Infantilisation, on the other hand, will always give rise to resistance just like the infantile perspective has been challenged by several textual devices.

In their complex narrative modality, the examined novels avoid the oversimplification and objectification of the subaltern challenged by Gayatri C. Spivak, while they clearly give narrative voice to the double-suppressed infant positions. Besides the textual devices of limited focalization and present tense narration, these novels invite the reader to actively participate in the dictatorial world instead of talking about the object of disempowered human situations.

These novels can make the reader feel and understand a special Eastern-European subaltern experience: growing accustomed to the unacceptable, to the dictatorial circumstances. Studying further the cultural trope of "growing accustomed" as a typical East-European cultural inheritance, a way of living and surviving seems a promising perspective that can make a valuable contribution to the theoretical discussions on the subaltern.

The present tense may also suggest an alternative relation to our regretful past that is neither denial nor feigned ignorance about it. We can have both an intimate and critical relationship with our dictatorial past at the same time. Even if a critical approach is usually associated with scholarly neutrality and not intimacy, with the help of these works of art we can initiate a new relationship and a new dialogue with our past. Whether we like it or not, we who were born and will be born in the Eastern part of Europe are the children of the communist system. And as such, we will always carry an inconvenient intimacy with our own stories which can never be satisfactorily and reliably told.

Notes

1 I am not talking about those novels in which an adult narrator recalls memories from his childhood during the communist era.

2 Not yet translated into English. The English quotations from this novel are my own translations, strictly for the purpose of this paper. 


\section{References}

Barnás, Ferenc, 2006. A kilencedik. [The Ninth, translated by Paul Olchváry, 2009, Northwestern University Press] Budapest: Magvető.

Bartis, Attila, 2001. A nyugalom [The Tranquility]. Budapest: Magvető.

Booth, Wayne C., 1983; 1961. The Rhetoric of Fiction. Chicago: University of Chicago Press.

Butler, Judith, Guillory, John, Thomas, Kendall, 2000. Preface. In: Judith Butler, John Guillory and Kendall Thomas, eds. What's Left of Theory? New Work on the Politics of Literary Theory (Essays from the English Institute). London: Routledge, viii-xiv.

Chakrabarty, D., 2000. A Small History of Subaltern Studies. In: Henry Schwarz and Sangeeta Ray, eds. A Companion to Postcolonial Studies. Malden, MA: Blackwell, 467-485.

Cherniavsky, Eva, 2011. The Canny Subaltern. In: Jane Elliott and Derek Attridge, eds. Theory after Theory. London: Routledge, 149-162.

Cooper, Thomas, 2009. A Child's Eye View of Socialist Hungary. Ferenc Barnás: The Ninth. Available at: http://ferencbarnas.com/en/reviews.php?o=thomas-cooper-a-childs-eye-view-of-socialist-hungary

Dragomán, György, 2005. A fehér király [The White King]. Budapest: Magvető.

Dunajcsik, Mátyás, 2006. Egy lépés hátra [One Step Back]. Holmi, 18 (1). Available at: http://www.holmi.org/2006/12/ket-biralat-egy-konyvrol-barnas-ferenc-a-kilencedik

Erdős, Virág, 2000. Lenni jó [Good to Be]. Budapest: Magvető.

Fludernik, Monika, 1996. Towards a "Natural Narratology". London: Routledge.

Garaczi, László, 2001. Pompásan buszozunk [We Bus in Splendor]. Pécs: Jelenkor.

Horváth, Györgyi, 2006. "Semmi sem tart örökké”. Rakovszky Zsuzsa: A hullócsillag éve ["Nothing Lasts Forever." Zsuzsa Rakovszky: The Year of the Falling Star]. Available at: http://www.litera.hu/hirek/\%E2\%80\%9Esemmi-sem-tart-orokke\%E2\%80\%9D

Kertész, Imre, 1975, Sorstalanság [Fateless]. Budapest: Magvető.

Kukorelly, Endre, 2003. Tündérvölgy [The Fairy Valley]. Bratislava: Kalligram.

Németh, Gábor, 2004. Zsidó vagy? [Are you Jewish?]. Bratislava: Kalligram.

Nünning, Ansgar, 2008. Reconceptualizing the Theory, History and Generic Scope of Unreliable Narration: Towards a Synthesis of Cognitive and Rhetorical Approaches. In: Elke D'hoker, Gunther Martens, eds. Narrative Unreliability in the Twentieth-Century First-Person Novel. Berlin: Walter de Gruyter, 29-76.

Phelan, James and Martin, Mary Patricia, 1999. The Lessons of "Weymouth": Homodiegesis, Unreliability, Ethics and The Remains of the Day. In: David Herman, ed. Narratologies: New Perspectives on Narrative Analysis. Columbus: Ohio State University Press.

Prince, Gerald, 1987. Dictionary of Narratology. Lincoln: The University of Nebraska Press.

Rakovszky, Zsuzsa, 2005. A hullócsillag éve [The Year of the Falling Star]. Budapest: Magvető.

Riggan, William, 1981. Pícaros, Madmen, Naifs, and Clowns. The Unreliable First-Person Narrator. Norman: The University of Oklahoma Press.

Spivak, Gayatri Charkravorty, 1988. Can the Subaltern Speak? In: C. Nelson and L. Grossberg, eds. Marxism and the Interpretation of Culture. Urbana: University of Illinois Press, 271-313.

Spivak, Gayatri Charkravorty, 1999. A Critique of Postcolonial Reason: Toward a History of the Vanishing Present. Cambridge, MA, London: Harvard University Press.

Szirák, Péter, 2003. Kertész Imre. Budapest: Kalligram.

Tóth, Krisztina, 2001. Porhó [Snow Dust]. Budapest: Magvető.

Tóth, Krisztina, 2011. Vonalkód [Barcode]. Budapest: Magvető.

Waxman, Jeff, 2009. The Ninth by Ferenc Barnás. Available at: http://www.rochester.edu/College/translation/threepercent/index.php?id=1965

Yacobi, Tamar, 1981. Fictional Reliability as a Communicative Problem. Poetics Today, 2, 113-126. 